\title{
Territorial Analysis in Environmental Studies on Fisheries: A Question of Scale and Spatial Representation
}

\author{
Christian Nunes da Silva, João Marcio Palheta da Silva, Clay Anderson Nunes Chagas \\ Federal University of Pará,(UFPA), Belém, Brazil \\ Email: cnunes@ufpa.br, impalheta@ufpa.br, claychagas@ufpa.br
}

Received 9 July 2014; revised 26 August 2014; accepted 12 September 2014

Copyright (C) 2014 by authors and Scientific Research Publishing Inc.

This work is licensed under the Creative Commons Attribution International License (CC BY). http://creativecommons.org/licenses/by/4.0/

cC) (7) Open Access

\begin{abstract}
In recent years, several technologies have helped human society to make better use of the resources provided by nature, which can be in continental environments, such as aquatic environments. However, the use of human resources occurs in a different way: some are rudimentary and others with use of appropriate technologies, seeking for a better management of the use of resources. In activities related to fishing, this fact can be observed, with the use of new technologies which has added increasing importance to this activity. Considering that the areas where fishing is developed, extension and expression have varied-local, regional, national and even global level, however, the scales and techniques used to study fish are likely to be represented in digital media and monitored through software and hardware called geo-technologies. This paper aims to analyze the use of geo-information techniques in environmental studies-focusing on fishing activities and in what ways, the issue of territory, the scale study, and the use of these geo-technologies favoring fishing activities. Thus, we seek to demonstrate the use of these methods as a subsidy in territorial planning and management of fishery resources.
\end{abstract}

\section{Keywords}

Territoriality, Fisheries Studies, Geoinformation, Scale, Geotechnologies

\section{Introduction}

Fishing is one of the most productive activities for humanity, constituting a source of protein, trade, income and leisure for fishing communities, being artisanal, sports, industrial or others working with fisheries, or who develop activities directly or indirectly aimed at the extraction of resources from the aquatic environment. This ac- 
tivity in Brazil has undergone profound changes over the last century since the establishment of the fishermen colonies [1], until recent technological advances in transportation and storage of fish (faster engines, refrigerator rooms on ships etc.), besides the increased demand for fish and new ways of management that are processed at the local level [2]. Nevertheless, these modifications only helped in the increase of pressure on fish stocks, causing major negative environmental impacts among the population that survive fishery.

Among these advances in fishing activity, one notices nowadays the use of new technologies for the location and assistance with fisheries management, for instance, the use of satellite images and geo-processing techniques [3]-[7] in environmental analysis and for the location of boats and shoals, as well as generating of information on the best seasons of the year to fish. The so-called geo-technologies must be understood as application of the remote sensing techniques: the use of softwares, hardwares etc., specialized in geo-processing techniques, as well as techniques for the creating of Geographic Information Systems (GIS) that focus on the interpolation and of geo-referenced spatial data. In other words, these techniques are directed towards the generation of geoinformation $^{1}$, and spatial information that assists man in the detection of phenomena and objects, not only on the continent, but also in the aquatic environment.

These aspects, the geo-technologies besides the use of softwares, hardwares etc. specialized in geo-processing techniques allow generating different scenarios (vegetation, soils, location of paraphernalia etc.) that can be crossed with information on fishing activity. These techniques provide the user with the development of new methodologies for analyzing geo-information, besides facilitating the assessment and diagnosis of distant phenomena of the local decision making, rather than just a tool for visualization of spatial information and becoming a tool for planning and land use [8]-[10].

It is intended with this work to discuss/talk about the following questions: How to represent spatial the territories of fishing activities, which are dynamic/changeable/unstable in computing environments, presenting themselves as static/permanent? How to break the problem of "vertical integration" of the water column in fishing spots and its representation in a cartographic product? What is the appropriate scale-local/micro, regional/macro or "multiscale" in order to analyze the activities that take place in fisheries, being the ecological relationships of the fish or the social relations of fishermen? Is there a problem in the multiscale representation of fish environmental studies? How to interpolate geographic areas-polygons, with spatially dynamic and punctual data?

Thus it is proposed that with this work, we discuss these questions. However, further analyses are necessary, since the technological advancement in the call "science of geo-information" is constant and the fishing industry cannot be deprived of such advancement. What can be verified for the future is the aggregation of such technology to all sectors of human activity, not only to fishing, which is an important tool in planning and monitoring of the actions that man performs over the geographic space.

\section{Territorial Analysis of Fishing and Its Spatial Representation}

Territoriality can be proven in any study that aims to analyze how the performance of the society is in the geographic space. Thus, the ways of life and territoriality are the products and reflection of the performance of individuals in space and use of natural resources. These ways of life of fishermen and fishing territories themselves affirm, interact, otherwise do not speak in way of life and territory-humanized, but rather only the common characteristics of living animals, which interact with the space making it a mere support for life, without thinking about it and without construction, then without intentionality. This way, in the analysis of territoriality of fishermen it is verified that several mechanisms and/or processes are part of the training of their ways of life and their territoriality.

With multiple realities/territorialities, it is verified that the fishery is complex. Mechanisms and techniques such as geo-processing, tend to optimize the actions of fishermen - artisanal and industrial, and the government, despite the "open access". It is notorious that in reality the fishing areas have an "abstract" territorial delimitation that requires rules and agreements between fishermen [11] and which may be intermediated by governmental agencies. In this sense, the mapping techniques have assisted the planner for best use of space managed by him, in order not to deplete resources and optimize the uses. The cartography is an essential tool when it comes to land use for any human activity.

\footnotetext{
${ }^{1}$ According to Câmara and Monteiro [12], the fundamental object of science is the study of geo-information and the implementation of different forms of computational representation of geographic space.
} 
Therefore, with reference to fisheries management, cartography can also be very useful, because it concerns an environment that can be spatialized, so it can be represented cartographically in a computing environment. However, what one observes is that in this activity geo-information techniques are still timid, underexplored and without the visibility necessary to improve the management of fishery resources within the national territory, being necessary prior knowledge of local fishing of fishing grounds, to be able to map out the fishing activities and their territorialities [13].

In this regard, the daily interactions of fishermen with the space where they live results in the territorialization of aquatic environments, as long as there is a relationship of possession of the same. Despite, in some instances, these territorialized spaces are not recognized by the authorities, there is the notion of respect among fishermen and/or other users. This appropriation of spaces does not occur randomly, but in accordance with the guidance of socio environmental phenomena that direct human activities for a specific purpose, either in search of natural resources, or by occupation and socio-political use of space for adding value to the "land use". When one has the appropriation of space by an individual or a group of individuals, one configures the power relations and ownership of that space, which becomes territory. In this case, the concept of territory is shown as crucial for understanding the processes of planning that is intended for a particular activity, because the notion of order is related to the question of use and power in the geographic space, as from the territorial delimitation.

The recognition of territoriality of fishing activities with all its techniques and fishing gear, as well as ownership of natural resources in general, are part of the customs, are soon among the ways of life that characterize the fishing grounds. Raffestin [14], in his study of the territory, states that it forms from the space is the result of an action performed by a syntagmatic actor at any level and appropriating of a space, concrete or abstract, this actor "expand the territory" and that space shall make use of features of the new territory conformed. However, the case of fisheries it is important to check that whoever is expanding the territory of the fisherman because this is an action-presupposes where the fish is just the existing natural resource in the space, whereas support exists and unintentionally.

This production from the space is made through the use that society performs on the territory. The social actors accomplish their political-economic-social actions territorializing social practices for their residence on it. But not always territorial practices are revealed as desired by its social actors, because they depend on a number of trading factors and conflicts involving nearly always more of an interest on the territory.

Thus, one of the factors that enable the execution of territoriality in the fishing activity are the uses given to fishing equipment—paraphernalia, used in the capture of ichthyological species, requiring a limited work space. Therefore, according to the use of the fixture will be delimited its territory, being that if that territory is "invaded" there may be consequences for the fishermen themselves and automatically about their territoriality, as result having conflicts of the fishing activity [15]. These conflicts can occur in several ways, fisherman to fisherman, fisherman with riverside communities, artisanal fishing to commercial fishing, with tourists and others. This demonstrates that territoriality can be proven in any study that seeks to analyze how the ownership of a particular natural resource is developed in the geographic space. Figure 1 shows an example of what occurs in river fishing and in many other places of fishing on the high seas [16].

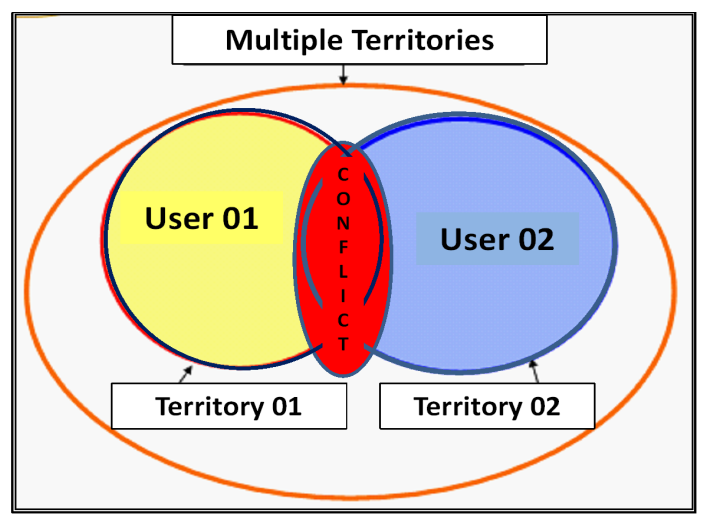

Figure 1. Simplified schematic model of using the territory and its resources (source: Elaborated by the authors). 
In the simplified model above, the user is not restricted only to fisherman, but to any user of natural resources, i.e., lumberman, tourism, extractivism etc. using the rivers for transportation or resource extraction, whether they are aquatic or not and reflecting on conflicts over ownership of this resource. In this way, the territory will have a fundamental understanding of the expression in the development of activities that use or extracting natural resources make it possible to differentiate the use as a social process, which provides individualization of the characters involved in its construction, by increasing their equity-territory. At the moment the conflicting territoriality emerge among the characters that make up the space, starting from appropriations present themselves evidence that the forms of territorial management-land-use plans should take into account the diversity of actors and interests, in order to be able to understand the various existing territorialities in the appropriate space.

In the case of fishing, in aquatic environments exists a boundary recognized by fishermen, accustomed to these fish locations where "disrespect" present conflicts that may cause the loss of life. This reality is also possible when the mobility of fishermen is lower, or in coastal environments where industrial fishing is a significant competitor [16]. In river and lakes environments [13] [15] [17] [18], no great mobility occurs, e.g. the need for fishermen to extract resources in remote locations, as it occurs in open sea because in most fisheries-regarded as the fishing grounds are located close to the houses of fishermen or their communities, making it a peculiar feature- a type of "sedentary fisheries" where the fisherman collects in a single region, close to his home, as well as the fixed gear and fishing, which are also located close to their homes.

So, how to study such complex activities where there is variability climbing and environmental? The particularities of the fishing activity - environmental ecological and economic instability, fluidity etc., become knowledgeable of the water environment from which they extract their sustenance [19]. Nevertheless, despite the complexity of the definition of fishing grounds for scholars of continental activities [20]-[22], the exact area in fishing environments can be estimated according to the methods of analysis of spatial perception and geographical analysis of the study area.

The fishing grounds - the fishing territories/fishermen, as well as their areas of influence-adhere to a set of regulations that are created by the very fishermen, establishing the concept of individual or collective power and express themselves in own spatializations, that have natural features- the existence of resources and are regulated by habits and customs of the fishermen/users. For example, the reference of a fishery is usually identified by a natural resource, a tree, a bush, a stream, position of a heavenly body etc., where the fact that the overlap of different fishing and other areas where the demand for fish is greater and higher incidences of conflicts can occur between fishermen, considering that often are points that are not territorially demarcated by visible boundaries, but by fishing rules that can be broken with/without user intent.

In this regard, one must also bear in mind that some species of fish frequent specific regions of a river or the sea, for example, the demersal species-benthic communities and those who frequent more strongly to water column, near the surface-pelagics, which demonstrates also the spatial variability of these fish, wherein the computerized environment in most cases is not considered, once it is represented on the map merely the phenomenon as a dot or polygon, seen "from above", showing a space that can be perceived instantly as homogeneous, which is not true because as marine biology have studied for some time the catch is not located merely in one place in a body of water. In Figure 2(a) and Figure 2(b) it is hereby confirmed what was shown in Figure 1, and endeavors to show this fact alluded.

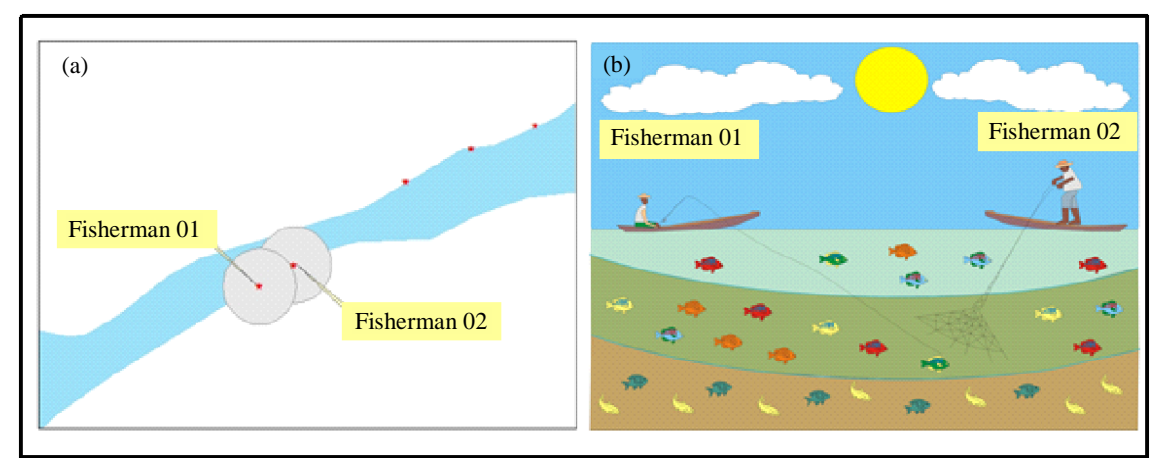

Figure 2. Two possibilities "to see the phenomenon in fishing” (vertical and horizontal). (source: Organized by the authors). 
In Figure 2(a) one can see the fishing activity view "above", as commonly observed in traditional fisheries studies, where a point or polygonal pattern of activity occurs that does not consider the deepest part of the aquatic environment where the fishing phenomenon happens, but only the information of the occurrence of an activity at the time mostly their extraction. In Figure 2(b) the cartographic representation considers the different environments, according to the "vertical integration" of water column found in the aquatic environment, where it is observed-symbolically the different habitats for distinct species of fish, that can be influenced by the characteristics of the water body, such as: acidity, turbidity, luminosity, temperature etc., interacting with the depth of the water body and in most studies on fisheries, characteristics are neglected when developing cartographic products, due perhaps to the complexity of analyzing and unawareness of the ecology of most existing aquatic species [16] [20] [23].

However, for Cruz and Menezes [24] at some moments the spatial representation of a phenomenon or object does not require precise positioning as in the case of fishing for its instability or by the occurrence of the phenomenon, as example in the case studied here, a fishing area map. Nonetheless, when it comes to fishing it becomes important that there is concern about the occurrence of a correct approximation of the distribution, because this approximate location depend on extraction productivity of fish, it is indispensable for a cartographic base precisely compatible user needs. In this sense, the scale of study and action may vary depending again of what the user expects to capture and quantity which craves, causing thereby the variability of what is perceived as a territory.

\section{The Question of the Scale in the Environmental Analysis on Fishing}

Research in the area of geo-information in fishing activity, commonly, do not adopt the name "geoinformation" for their activities of spatial objects and phenomena studied in fishing. However, they use techniques related to cartography and geography for handling and disclosure of their data through cartographic products, generally, represented by maps and cartograms. Efforts in order to test new technologies in fisheries are being conducted in the national territory and other countries most of the time in the context of higher education institutions and yet little explored in government institutions, that monitor or supervise the fishing activities.

These geo-technology are already inserted some time in other fields of human activity, como mineração, transports etc., although, use in fishing activity, except for the Global Position System (GPS), still barely visible, but tends to increase due to the importance it has taken in recent years because, in a GIS environment, for example, the accumulation of geographical information-in local or global levels and the possibility of the relationship of spatial data and attribute of these geometries, with speed and agility in processing of cartographic product generation, strengthens the processes of decision making and planning by the user, since a GIS allows grouping, automatically collecting and analyzing spatial information, in order to be more optimized and faster than was possible with traditional research techniques - especially in analog format.

However, when using geo-processing tools, such as GIS, One can not ignore the data from field activities, much less, One can not ignore the data from field activities, much less, the different that are interrelated with the form of appropriation of space and rationalized use of natural resources, so that there is overlapping of scales with regard to regulation of the use of these natural resources. Currently, except for the tactile maps and models, most cartographic products (maps, charts, plans etc.) can be represented in computational media, which allows the user the ability to view/temporary demonstration of a specific geographical information, where a certain space is presented according to the will and the need to be viewed by the user [24].

These types of map can demonstrate the dynamism of actions on the Earth's surface, for example, of fishing activities, which according to their mobility characteristics, seasonality and instability etc., may represent the flows of fisheries and fishermen, and movements beyond the temporal, climatic and ecological changes which influence the fisheries productivity. In all studies the environmental analysis of this volatility can be improved/enhanced with the use of remote sensing and GIS programs that enable the generation-in real time of spatial geo-information linked to the phenomenon analyzed, with the possibility of different interpolation and simultaneous information presentation through symbols and cartographic conventions internationally accepted. Although, for Cruz and Menezes [24] this representation is not only restricted to computerized presentation, because the display can also be demonstrated by copies, assuming that in this case the preview feature of paper maps, where information is made permanent, making it difficult to update the cartographic product, except for the construction of a new map. 
The main requirement for any phenomenon can be represented on a map is the association of spatial or geographical distribution. In other words, must be known and clearly defined its occurrence on the earth's surface. This is the link between the phenomenon and the map. Thus, any phenomenon that is spatially distributed is likely to have represented their occurrence on the earth's surface through a map. A well characterized phenomenon is known as geo-referenced [24].

Therefore, as shown in the citation, regardless of the form of presentation of the cartographic product one must know the phenomena inherent to the objects to be represented, as when considering the use of fisheries resources again, for example, it must be emphasized that the precise knowledge of the ecology of the majority of all species of commercial and non-commercial fish is still unknown, mainly due to the great diversity of species, or the fact that some species are more sought—commercially (then others) follows the search by knowing only the main ecological characteristics of the most profitable species.

Accordingly, in relation to the scale, one can generally define it as a relationship between the size of the object represented on the map-starting from their geometry and attributes and their size in real space. When one speaks in drafting a cartographic product, it is important to mention that the scale will always be present at any level of mapping exercises, being considered a determinant factor in defining the physical space degree of detail of a representation or identification. In analog terms, on printed maps, the scales remain unchanged only changing when reproducing copies or preparation of new maps. In computational terms, however, the issue of scale can be a complex factor, once the scale maps show the relative independence of the digital basis [25] [26], i.e. in most of the software geo-technology, "the functions towards and away from (zoom in and zoom out) providing a sense of independence of scale, since they can generate a series of views on continuous scales" [24], this means, the possibility of unlimited zoom can generate "illusory maps" in the interpretation of its contents. Speaking of the choice of scale, Fitz [26] informs that:

In the case of maps stored in digital files, this situation tends to be relegated to the background, because in principle, the scale can be easily changed to any values. Nevertheless, this can create a lot of problems. One should be very careful when dealing with this type of structure, because what actually matches the reality is the source of the information generated. Thus, a map created in digital media, originally conceived on the scale 1:50,000, will never have better accuracy than allowed for this scale (Remember This) [26].

In such cases, as seen in fishing activity, one can speak of "multiscale" within the computing environment but at the time of transfer to the analog model map scale will be one, according to the scale of the base map source and due to its permanent feature when printed, but varied when taken into account differing scales found in the cartographic database that generated the final cartographic product-is based on a vector or raster in a computerized environment. It is complex, however, establish the threshold for each scale, because the concept of large, medium and small is very subjective, and this association to a numeric value is set to establish a reference to the relative size of objects presented in real space, where it is possible to classify them according to global, regional and local characteristics, but also in a very subjective way, generating controversy upon its association to numerical scales and the final representation of the environment [27].

As a suggestion in choosing the correct scale work in environmental studies, and here be inserting fishing activities, Silva [27] analyzes the different work schedules are determined according to the aspects that define both the location and extent of events and entities, about the properties and relationships of these components, which generate certain situations studied, due to the "geographic scale factors and geo-economic". For this author [27], commonsense recommendations and reflection on the application of the recommended use of this form of analysis procedures, where one can distinguish four levels of causality in a geo-environmental scale:

1) Local level: Mainly refers to situations that occur on municipal scale, with emphasis on the surveys which take into account the environmental resources available physical, biotic and socioeconomic). In these respects, the scales of representation at this level of causality are of 1:50,000, for the treatment of municipal area as a whole, and 1:10,000 for the analysis of processes and phenomena that take place in specific local areas, in case of fisheries the representation would be in fishery well defined territorially, in the catchment area of a municipality in question;

2) Intermunicipal level: At this level of causality is considered the dependence of events and processes that exist in the inter municipal space, the interaction between municipalities and their political-administrative boundaries. Silva [27] emphasizes the importance of this approach for studies directed research in geoprocessing, of small watersheds, which typically cover the area of more than one municipality. The geographical scales of data processing for that level of environmental analysis are 1:50,000 and 1:100,000 [27], in the Brazilian terri- 
tory, these scales cover with relative detail the processes that unfold in inter municipal level, and fishing, facilitate the analysis that can be made between conflicts of fishermen from different municipalities that operate in the same region;

3) Regional or national level: For Silva [27] one should understand that scale level as the area encompassing the "judicial power coupled to a nation which could be the director of research strictly within its territory". However, this scale level exceeds often the national territory of fishermen or historical-political boundaries, only one nation such as the Amazon region, observed by the author or in studies that analyze the delineation of watersheds that does not adhere to political boundaries but the environmental issues. In this particular case, Silva [27] explains that the analysis can be supranational, regional or respecting the concepts of the nation and national territory. At this level of causality the author shows scales of 1:100,000 and 1:250,000.

4) Global level: For Silva [27] this level of detail refers to the economic-demographic system on a global scale, "for actions or phenomena that affect the world's population, in particular by warn for problems related to depletion of non-renewable natural resources". One realizes that by trying to synthesize the complex reality, this level of causality is extremely criticized, although advances in geo-technology have enabled further analysis on a global level. The author suggests that the scales of treatment at the global level are of 1:1,000,000 or less and has direct military-strategic and geopolitical connotation. Based on these levels of causation Figure 3 seeks to simplify how you can work with cartographic products, in a computational environment according to "multi-scale".

Thus, from the analysis of the levels of causality proposed by Silva [27] and simplified in Figure 3, geo-information can be represented in different ways in different scales, it is observed that the that depend on the demand and mode of investigation of the end user, enabling different levels of detail and various forms of interpretation. Therefore, when choosing the working scale, professionals who use geo-processing should use the structures analysis compatible with the environmental complexity that they face, according to Cruz and Menezes [24] the larger cartographically scale represent a level higher than that of smaller scales detailing, approaching in turn a smaller geographical area.

Thus, the scale size, or the level of causality will depend on the type of study that the researcher is doing, which will cover a specific area according to the object or phenomenon studied. In the case of fishing activity, the local level is appropriate for studies of fish species that maintains a small performance area; hence the maps will be prepared on a large scale that is reflective of the variety of details found in the cartographic product. For studies that reflect the migratory species, regional and even global, is the most appropriate because it encompasses all moments of life of fish, from birth to maturity and reproduction.

However, it is currently visible efforts to conceptualize and better understand the activities in computer environment using geo-processing tools. In this sense, appears in recent years to the proposal of the so called "digital territory, which can be considered as forms of computer representations of geographic space" where those areas exist in reality are represented on the computer screen and manipulated to the various scales that geo-processing tools offer, as seen before.

With this idea, which has been widespread in recent years, the scale takes "multiscale" sense, appropriate to the user's work, where the base map used is diverse and widespread is common, starting from the accumulation

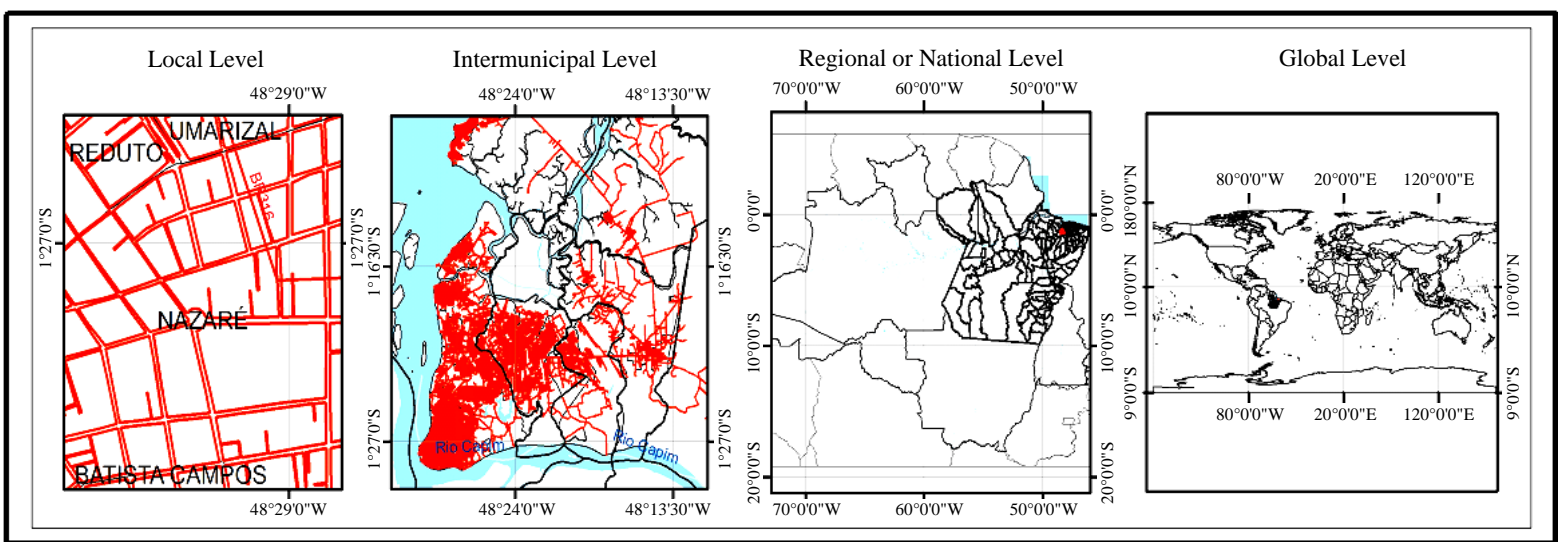

Figure 3. Levels of causality, according to the research object and different scales. (source: Organized by the authors starting with Silva [27] and Cruz and Menezes [24]). 
of knowledge that the user has the represented space and the contributions of different types of knowledge for the generation of the final cartographic product.

In this type of cartographic representation, yet to be defined categorically, actual territories, contained in geographic space, tend to be represented in GIS environments where the scale variability would be assured by the accuracy of data collected in real space and the elements of spatial reference that the user intends to show, in this way eliminating, secondary information, which may be omitted. In this example, the spatial information, existing in a Geographical Database (GDB), are arranged in registration form, where the geometry is guaranteed and attribute data are subject to editing, with the addition of new information or subtraction of unnecessary information. Such geo-technology can already be viewed as today WebGis tools available on the internet with specific themes, according to the convenience of its administrator.

It is important to inform that the potential for spatial relationships in these environments are feasible and can generate new information from various data interpolation with creating future scenarios or the discovery of other existing attributes in the present time. The ideas that threaten to digital territories are innovative propositions, directed to the geo-processing environments, where faults which must be tested and presented to the scientific community in the coming years are still observed. For fisheries, the concept of digital territories can mean a change in a change in the land use model known, in addition to environmental and ecological characteristics, may also be aggregated socio-cultural information that will encourage the analysis of the manager/user of fishery

\section{Conclusions}

From the conceptual discussion on fishing territory it can be seen that the use of geo-technologies is of fundamental importance for the (re)cognition of certain defined spaces at the present time. Furthermore with respect to monitoring and environmental surveillance applied by environmental agencies, it is noticed that these techniques are key allies to the fight against illicit activities or predatory activities which are processed by the Brazilian territory.

Generally speaking, fisheries studies, when considering its superficial coverage of a horizontal character, are similar to studies that analyze phenomena and objects in continental ecosystems. However, when presenting the aspects of vertical character, related to the water column in an aquatic environment, the complexities in working with fishery studies are added, where resources of different continental perspective can be defined with greater precision. In addition, this complexity tends to increase from the moment in which the fish are considered dynamic, such as, mobility, non territorial limitation, species in different aquatic environments, ecological seasonality etc.

The complexity of working with fishery studies shows the importance of this type of study for geo-processing, where the possibility of representing each element can be treated as a separate attribute, connected to a particular spatial geometry. In this way, when considering element by element, spatial relations appear as relevant, for example, to investigate the crossing of data on the ecology of species in watersheds and/or various aquatic environments (rivers, streams, lakes etc.).

The scale factor, before limiting element in the analysis of the printed map, becomes flexible when the cartographic product is disposed on a computer. Yet, one wants to encourage confusing generalizations that omit important elements in landscape studies, if one intends to pay attention to the need to generate effective and temporally agile tools and rapid development, which assist in analysis of ideal geographic space.

In this perspective, the development of GDB or the Geographic Information Systems (GIS), incremented by the emergence of remote sensing images of high spatial resolution with different spectral bands, are indispensable tools for planning and land use in fishing nowadays, especially when related to multitemporal analysis and thermal and climatic information, as necessary to identify different species of fisheries. Thus, the possibility of coupling of complex information, with a very large number of attributes, calls into question the proposal of analysis of digital territories as possible to be applied in activities such as fisheries, mainly due to the large amount of information generated by type of fish species. Nevertheless, the government's indecision regarding the use of geo-technologies fishing is visible, and has not benefited the activity of fewer fishermen who subsist it a fact that it tends to change, in view of the visibility for these tools which they had in recent years.

\section{Funding}

This research was funded by the Qualified Publication Support Program (PAPQ), offered by the Dean of Re- 
search and Graduate Studies (PROPESP) and the Foundation for the Support and Development of Research of Pará (FADESP), of the Federal University of Pará.

\section{References}

[1] Villar, F. (1945) A missão do cruzador “José Bonifácio”: Os pescadores na defesa nacional—A nacionalização da pesca e a organização dos seus serviços (1919-1923). Rio de Janeiro, Gráfica Laemmert.

[2] Berkes, F., et al. (2006) Gestão da pesca de pequena escala: Diretrizes e métodos alternativos. FURG, Rio Grande do Sul.

[3] Almeida Pinto, W.H., et al. (2007) Critérios para setorização e espacialização de dados pesqueiros na região de Parintins-AM e Santarém-PA. Simpósio Brasileiro de Sensoriamento Remoto, 13, Florianópolis, INPE, 3019-3026.

[4] Botelho, A.Z., Calado, H. and Costa, A.C. (2010) GIS-Based Marine Biodiversity Mapping for Assessment of Coastal and Marine Priority Áreas for Conservation. In: Calado, H., and Gil, A., Eds., Geographic Technologies Applied to Marine Spatial Planning and Integrate Coastial Zone Management, Universidade dos Açores/Centro de Informação Geográfica e Planeamento Territorial (CIGPT), Ponta Delgada-Portugal, 31-37.

[5] Garcia, L.M., et al. (2010) Geographical Information Systems (GIS) as a Tool for the Environmental Evaluation and Management of Coastal Area of Tazacorte, La Palma, Canary Islands, Spain. In: Calado, H. and Gil, A., Eds., Geographic Technologies Applied to Marine Spatial Planning and Integrate Coastial Zone Management. Universidade dos Açores/Centro de Informação Geográfica e Planeamento Territorial (CIGPT), Ponta Delgada-Portugal, 53-60.

[6] Lozano-Rivera, P., Garcia-Valencia, C. And Rodrígues, A.L. (2010) Geographic Information Technologies for Integrated Coastal Zone Management in Colombia: A National Experience. In: Calado, H. and Gil, A., Eds., Geographic Technologies Applied to Marine Spatial Planning and Integrate Coastal Zone Management. Universidade dos Açores/ Centro de Informação Geográfica e Planeamento Territorial (CIGPT), Ponta Delgada-Portugal, 86-93.

[7] Pitt, J.M. and Shailer, M.L. (2010) GIS Applications in Marine Resources Management: Examples of Spatial Management Measures from Bermuda. In: Calado, H. and Gil, A. Eds., Geographic Technologies Applied to Marine Spatial Planning and Integrate Coastial Zone Management. Universidade dos Açores/Centro de Informação Geográfica e Planeamento Territorial (CIGPT), Ponta Delgada-Portugal, 103-111.

[8] Zagaglia, C.R., Brichta, M. And Cabral, D.H.G.S.L.B. (2007) Mapas de gestão pesqueira como base para o Programa Nacional de Rastreamento de Embarcações Pesqueiras por Satélite e demais atividades do IBAMA. Simpósio Brasileiro de Sensoriamento Remoto, 13, Florianópolis, 4339-4341.

[9] Câmara, G. and Carvalho, M.S. (2004) Análise espacial de dados geográficos. Embrapa, Brasília.

[10] Jensen, J.R. (2009) Sensoriamento remoto do ambiente: Uma perspectiva em recursos terrestres. Trad.: José Carlos Epiphanio (coord.). São José dos Campos, Parêntese.

[11] Ruffino, M.L. (2005) Gestão do uso dos recursos pesqueiros na Amazônia. IBAMA, Manaus.

[12] Câmara, G. and Monteiro, A.M. (2001) Introdução da ciência da Geoinformação. São José dos Campos, INPE, 07-41.

[13] Cruz, M.N. and Almeida, O.T. (2009) Estratégias para a co-gestão dos recursos pesqueiros no estuário amazônico: O caso dos acordos de pesca em Abaetetuba-PA. Simpósio Nacional de Geografia Política, Território e Poder, UFPR, Curitiba.

[14] Raffestin, C. (1993) Por uma geografia do poder. Ática, São Paulo.

[15] D’almeida, B.G. (2006) Os acordos de pesca na Amazônia: Uma perspectiva diferenciada de gestão das águas. Encontro Preparatório do Conselho Nacional de Pesquisa e Pós-Graduação em Direito, 15. CONPEDI, Recife.

[16] Cardoso, E.S. (2001) Pescadores artesanais: Natureza, território, movimento social. Tese de Doutorado em Geografia, Universidade de São Paulo, São Paulo.

[17] Mcgrath, D.G. (1993) Manejo comunitário dos lagos de várzea do Baixo Amazonas. In: Gonçalves, L.G., Leitão, W. and Mello, A.F., Eds., Povos das águas: Realidades e perspectivas na Amazônia, MCT/CNPq/MPEG, Belém, 389402.

[18] Mcgrath, D.G. and Câmara, E.P.L. (1995) A viabilidade da Reserva de Lago como unidade de manejo sustentável dos recursos da várzea. Boletim do Museu Paraense Emílio Goeldi, MPEG, Belém, 87-132.

[19] Maldonado, S.C. (1993) Mestre \& Mares: Espaço e indivisão na pesca marítima. Annablume, São Paulo.

[20] Begossi, A. (2001) Mapping Spots: Fishing Areas or Territories among Islanders of the Atlantic Forest (Brazil). Regional Environmental Change, 2, 1-12. http://dx.doi.org/10.1007/s101130100022

[21] Begossi, A. (2004) Ecologia de pescadores da Mata Atlântica e da Amazônia. Hucitec, São Paulo.

[22] Begossi, A. (2006) Temporal Stability in Fishing Spots: Conservation and Co-Management in Brazilian Artisanal 
Coastal Fisheries. http://www.ecologyandsociety.org/vol11/iss1/art5/

[23] Guedes, E.B. (2010) Território e territorialidade de pescadores no Marajó: O exemplo das localidades Céu e Cajuúna, Soure (PA). In: da Silva, J.M.P. and Silva, C.N., Eds., Pesca e territorialidades: Contribuições para a análise espacial da atividade pesqueira, GAPTA/UFPA, Belém, 24-45.

[24] Cruz, C.B.M. and Menezes, P.M.L. (2009) A cartografia no Ordenamento territorial do espaço geográfico brasileiro. In: Almeida, F.J. and Soares, L.D.A., Eds., Ordenamento Territorial, Coletânea de textos com diferentes abordagens no contexto brasileiro, Bertrand Brasil, Rio de Janeiro, 195-225.

[25] Fitz, P.R. (2008) Geoprocessamento sem complicação. Oficina de Textos, São Paulo.

[26] Fitz, P.R. (2008) Cartografia básica. Oficina de Textos, São Paulo.

[27] Silva, J.X. (2001) Geoprocessamento: Para a análise ambiental. Edição do Autor, Rio de Janeiro. 
Scientific Research Publishing (SCIRP) is one of the largest Open Access journal publishers. It is currently publishing more than 200 open access, online, peer-reviewed journals covering a wide range of academic disciplines. SCIRP serves the worldwide academic communities and contributes to the progress and application of science with its publication.

Other selected journals from SCIRP are listed as below. Submit your manuscript to us via either submit@scirp.org or Online Submission Portal.
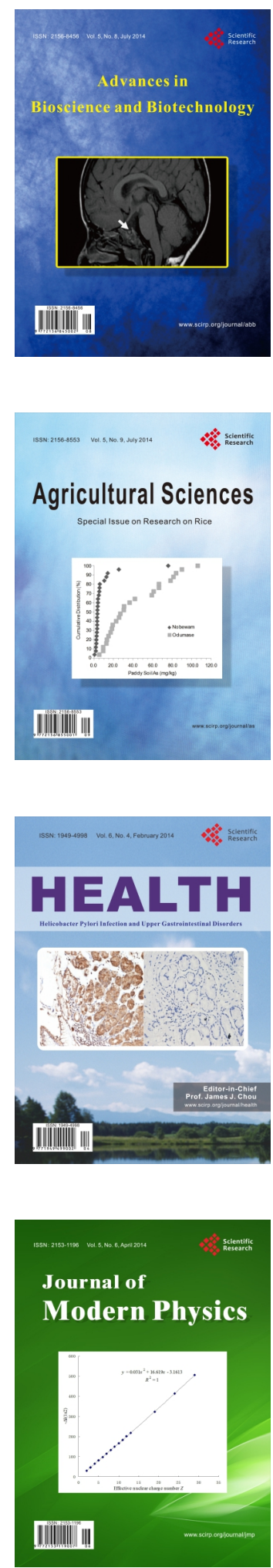
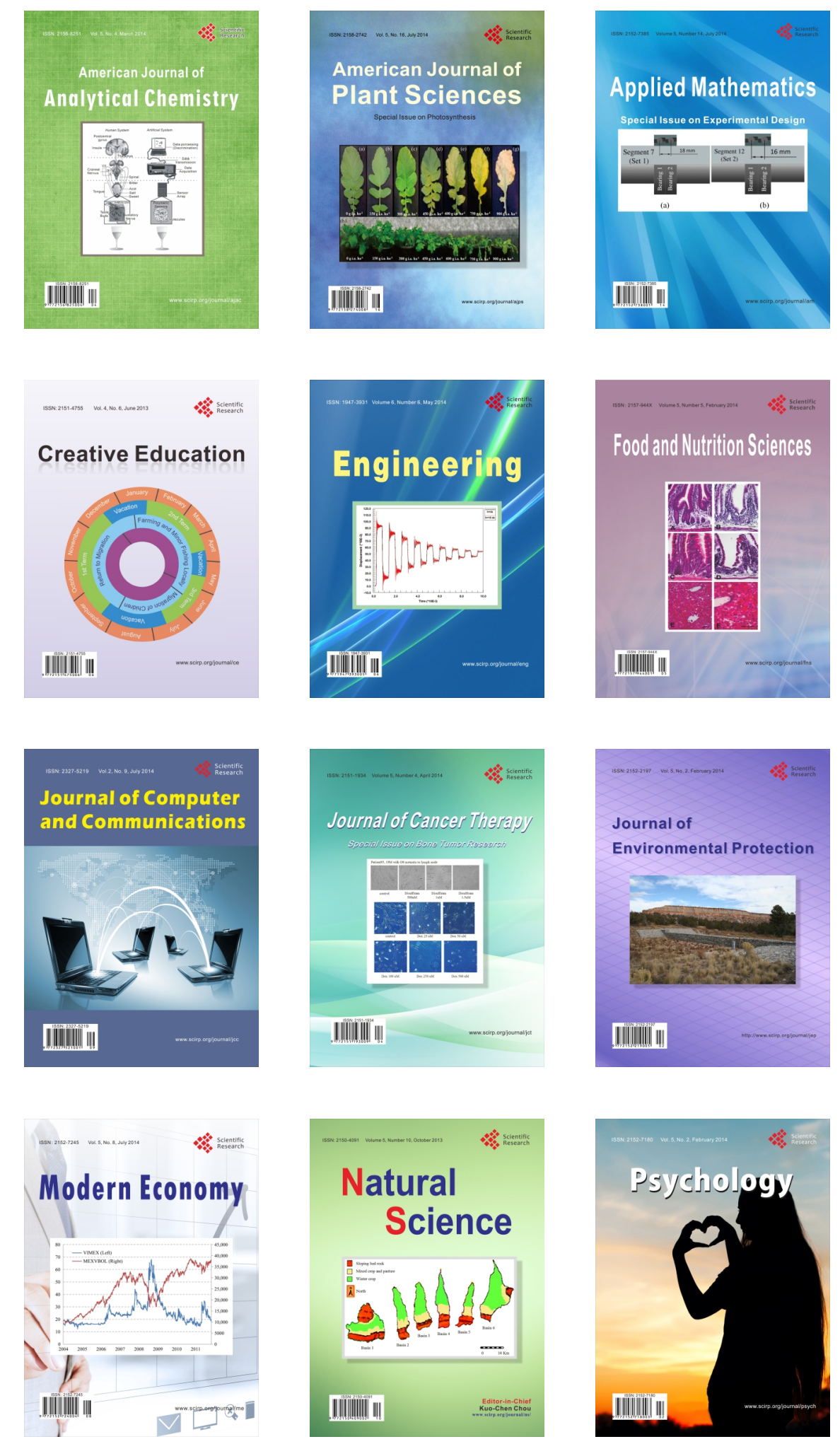